\title{
Resocialisation program "Miriam" as a Christian subculture group in female prison
}

\author{
R. Losane \\ University of Latvia, Riga, Latvia
}

\begin{abstract}
The paper aims to study the similarities and differences between small or informal groups in prison subculture and re-socialization program "Miriam", which is created as a different cultural space in female prison.

The dominating norms in the small groups in prison subculture the values, artefact, leader, table culture, and a sense of space and time strengthens the convicted person's criminal identity. Under the program "Miriam", which also has elements of prisoner small group subculture, women are offered to learn about different cultural and artistic values together with fundamental Christianity values by program leaders well-known people from Art and Culture area. With this kind of approach different cultural space is created in prison opposite to the prisoner subculture. And this creates favourable conditions for transformation of the convicted person's point of view.
\end{abstract}

Key words: prison subculture, convicted persons' re-socialisation, Christian program

\section{Introduction}

This research is part of my future doctoral thesis "Christian program "Miriam" and its role in transformation of the point of view of the convicted person." In Latvia, in the only female prison, the program "Miriam" has been running for fourteen years. In a separate division, separate from the other convicted women, in accordance with the regulations of the program, sixteen program participants live and study, admitted on their own initiative. "Miriam" is the author's program of the author's research. It has developed gradually, taking into account the specific character of female prison and needs of the convicted women. The aim of this program is to change the point of view of the convicted persons.

I believe that the long-term existence of the Christian program "Miriam" is due to the fact that over time it has been able to become one of the small groups of the prison subculture. According to Gene Edward Veith: "Even Christians have become a segment of society rather than an integral part of the culture. The church gradually is becoming a subculture" [1].

After institutionalizing the program in prisons and establishing a kind of subculture group, and by executing the re-socialisation work with the program participants, the program "Miriam", according to my long-term observations, is more likely to affect transformation of the convicted person's point of view as opposed to the rest of the re-socialisation work. This is also shown by the low recidivism percentage among the students of the program "Miriam." During fourteen years of existence of the program, 10-12 women out of 140 program participants have returned to prison. 


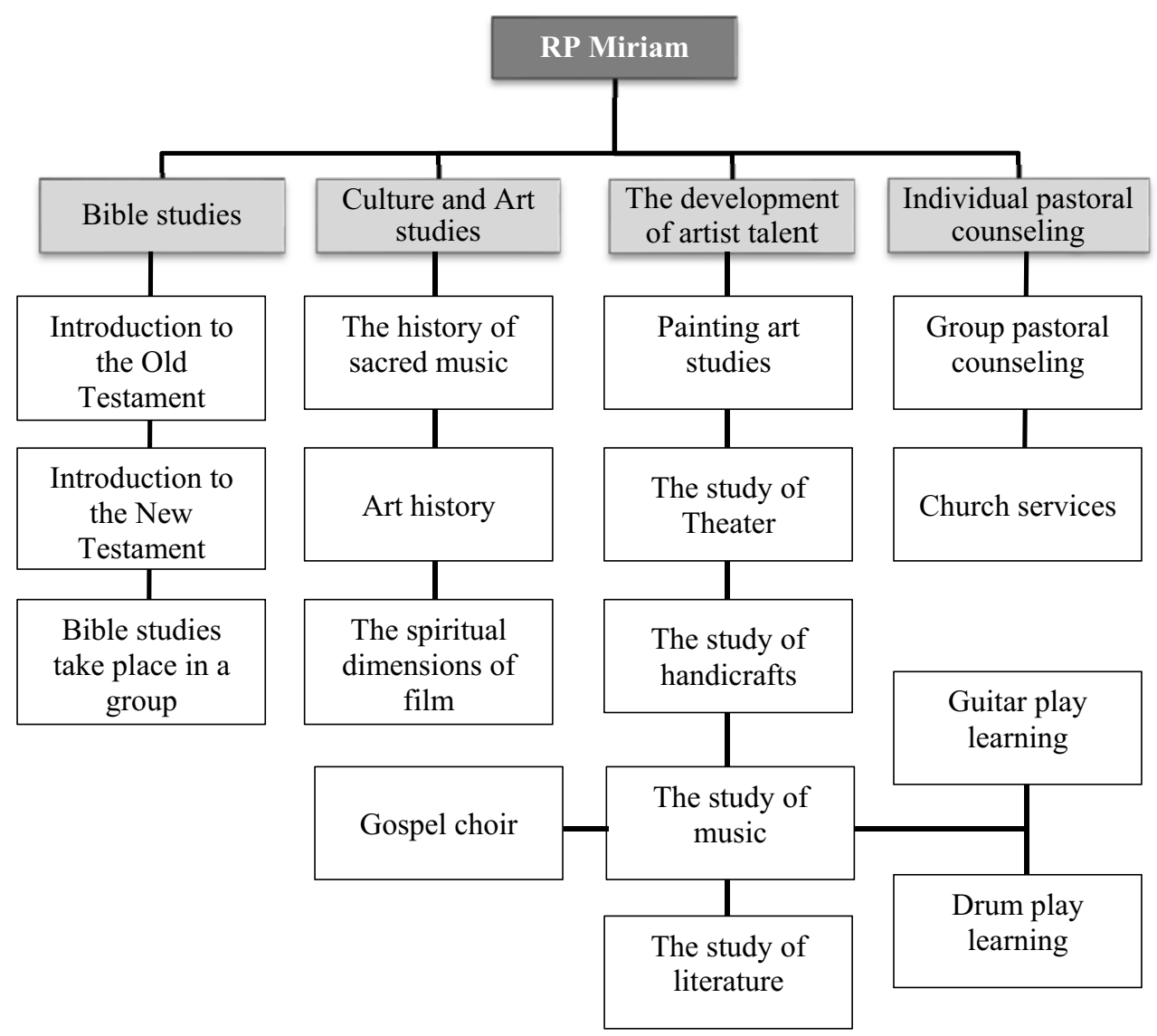

Figure 1. Graphical representation of the program "Miriam".

\section{The small group}

Both female and male prison subculture is characterized by the so-called informal or small groups. According to Lennie Spitale, "the average newcomer to prison experiences their will to be isolated from other inmates. Most, in fact, eventually gravitate toward a specific "group" in which they find social identity insecurity" [2]. In male prisons affiliation to one of these informal groups is dictated by the hierarchical order of subculture.

Female prisons do not have the pronounced hierarchy and role distribution, as in male prisons, however women form the so-called small groups on the basis of personal relationships [3]. From the feminist perspective such differences in the same gender communities are explained by the fact that by forming a group men tend to be oriented towards execution of specific tasks, the rules that govern the order of the group, using authoritative management style, and the results are ensured by the directives and aggressiveness. Whereas women, when forming groups, are more focused on relationships and they use democratic management style, focusing on building of the relationships [4].

Small groups in a female prison are composed of two or several women who share the same beliefs [5]. According to Joanne Belknap, in female prisons, these informal small groups are generally formed on ethnical and racial basis, the arrangement in cells, on 
the basis of political beliefs, the need to deal with everyday tasks, by kinship principle, etc [6]. In subculture language informal groups are called "families". I believe that successful precondition for integration of the "Miriam" program into social structure that is created by the prisoners, as well as for it to bring different cultural values, is the fact that this program is like one of the subculture groups, which has features of the small subculture group.

The main common interest and feature that unites women who live within the program "Miriam" is the desire to change, which they (women) write into the separate column: "Motivation: Why do You Want to Participate in this Program" - in different interpretations, while writing the application. This feature distinguishes the "Miriam" community from the other prison groups or "families", because in other groups the unifying interests have not been formulated in such manner.

However, being a group "Miriam" also has common features with other small subculture groups, and that helps to identify it with them, and yet to remain different.

\section{Leader}

The first and the most important feature of the small subculture groups in prison is that each group has its own informal leader. This leader is like the head of the family, whose functions include organization and coordination of activity of the total group, the care and maintenance of traditions, which is associated with the prison morality and ethics; as well as punishing or rewarding the members of the group [7].

Although female prisons do not have the expressed authorities or leaders, because there is no caste system, as it is in male prison subculture, still women also have local authorities or leaders. These are women who have a certain power. According to L. Spitale, in male prison subculture the power can be divided into several categories. The first category of power is the physical power. This category of power is ensured by the physical strength of the convicted person. The second category of power is political power. In prisons, crime lords and persons who are in close contact with them usually have political power. Political power is also possessed by those convicted persons, who have knowledge in the legal field and who can act as "lawyers", because they know how to write reports and complaints. The third category of power is the economic power. To this category of power belong those convicted persons, capable of providing prison with "currency" flow. Prison "currency" is - cigarettes, drugs, or the account money, the goods, which can be bought at the prison shop, the goods that the poorest prison inmates cannot buy. The fourth category of power is the power of popularity. The power of popularity is ensured by the fact that the other inmates like the convicted person, because of his pleasant nature. This kind of person has a lot of friends and few enemies. This means that this prison inmate has something that others respect. The fifth category of power is the power of reputation. It plays an important role in the prison environment. Respect or fear of a prison inmate, which is the feature of the power of reputation, is the most you can gain, says L. Spitale [8].

The leaders of the female prison can also be divided into above mentioned categories of power. However, power mechanism of the female prison subculture is not as structured as in male prisons. In female prison subculture, the power is ensured more by psychological and emotional strength of the convicted person rather than by physical strength. Joanne Belknap calls such women "prison mothers" [9]. According to my observations, in the female prison of Latvia economic power is not related to the drug trade, because the drug trade and drug use in the prison actually does not take place. However, economic power, in its own way is maintained by the convicted women who trade drugs in prison, and who do not intend to change their occupation after their sentence, and who have 
sufficient amount of financial means. They purposefully attract women drug addicts, helping them with products, creating a common table, thus preparing their product distributors and consumers after returning to freedom. The local cigarette traders, who otherwise are hated by other inmates, [10] also possess the economic power. However, almost none of the smoking women can manage without their trade, when their own stock is exhausted. In female prison the power of popularity is also possessed by the leading lesbians, who are "in demand" due to their orientation. According to my observations, popular lesbians often maintain such relationships, in order to gain financial benefits. Usually they choose a woman, who has a sufficient amount of financial means, and who could provide them financial support in prison. They can choose their "victim", as it is described in Maria Asare's book "Women Zone", by using special, inherent intuition [11]. The repeat offenders can also be numbered among the category of power of popularity. They are well-familiar with the harsh conditions of survival in prison. They usually do not engage in subculture activities, but are good advisers on how to survive in harsh prison conditions.

The program "Miriam", by forming its own subculture, has to offer its own leaders, "its own authorities", who propose different values that do not bind and enslave, but which release from prison subculture obligations. These leaders do not have power over the members of the community, but they have to be the leaders with authority, which is awarded to them according to liabilities of the program regulations.

Over time program teachers or volunteers become this type of "authorities" or leaders, because they, according to Lennie Spitale, "preach the good news". They are the paradox of the local prison culture. They smile, shake hands, touch, hug, they talk using kind, friendly words in culture, where almost everything that you see, hear, and encounter, can be described as tough. The prison is a culture of toughness" [12].

"Miriam" program teachers are intellectuals, the workers of culture and art, as well as recognized theologians with academic education. They receive no compensation for work within the "Miriam" program. The program teachers are interested in serving to the convicted persons. According to my observations, these factors encourage the program participants to trust the program teachers, and it is a prerequisite that they become a different type of leaders as opposed to the existing leaders of prison subculture.

The teachers of the program "Miriam" do not have the authority, as it is understood in the context of the prison, which is the power system, but they have the authority of a different meaning, - they are the persons, who enter the prison with a good public reputation; they are decent representatives of their profession, with a friendly attitude toward convicted women, and who are able to inspire the convicted persons to dare to be equal.

Robert K. Greenleaf calls such authorities "servant - leaders" (The Servant as Leader) [13]. Greenleaf's servant-leader is a person, who accepts and sympathizes, who listens and understands. Every once in a while a leader needs to think like a scientist, an artist, or a poet, in order to comprehend what is beyond the rational, who uses their rich intellectual potential to bring peace during stress conditions; it is a person who comprehends reality, but who at the same time is a historian, contemporary analyst, and prophet [14].

In most cases, the women are punished by deprivation of liberty when they understand liberty as wilfulness. According to Greenfield, teachers of the program as servant-leaders, come to the convicted persons with a natural desire to serve the needs of convicted people, which makes them (the convicted persons) free, in a sense as defined by M. Buber: "A free person is a willing person without wilfulness" [15].

R.Greenleaf writes, that the best way for the leader to carry out their work as a servant, can be identified by the results, finding out whether the served becomes spiritually healthier, 
wiser, freer, more autonomous, more likely themselves to become servants [16]. I would define it as follows - to identify, in accordance with the results, which confirm, whether there has been a transformation of the point of view of the convicted person, which is the aim of the research of my work. According to Greenleaf, this type of a leader, represented by the teachers of the "Miriam" program, contradicts not only the way the characteristic parameters of the leader are understood in prison subculture, but also the way these parameters are understood by the prison staff, because prison is based on hierarchical relationships.

However teachers are the leaders, who once a week come to prison and then leave it. In order to ensure the existence of the small prison subculture group, according to the features of the small subculture group, it has to have its own permanent leader, who is chosen from the members of the group, whose functions would include organization and coordination of the main group's activities, preservation and maintenance of the group's traditions [17], which is no longer related to prison morality or ethics, but rather to Christian morality and ethics.

The group of convicted persons of the program "Miriam" has its own leader, as it would be in a small prison subculture group. This leader is the "elder sister", whose status and responsibilities are set out in the program regulation. On the one hand the elder sister of the program has a formal status because she is appointed by the program manager. The program manager coordinates her choice with the prison administration. However, on the other hand, she also has an informal status, for when choosing an elder sister, the fact whether she is respected among the members of the group is also taken into consideration. The task of the elder sister is to take care of the daily arrangements, as well morning and evening common prayer. At the same time the older sister assists the program manager on the issues regarding spiritual care, for example, dealing with minor conflict situations within the group and paying attention to needs of the members of the group.

An important leader is the program manager, who within the program "Miriam" is the prison chaplain. She is also the prison worker, who has authority, delegated to her by the Prison Administration and head of the prison. Despite the fact that the rating of the prison staff among the convicts is low, the rating of the prison chaplain among the convicted persons is high, as recognized by L. Spitale [18]. In 1964 Daniel Glaser performed a research of the enhancement of the prison and probation system effectiveness. He found that the prison chaplain, who provides support to convicted persons during re-socialisation work, comes second in terms of importance among the prison staff [19]. The head of the group organizes and coordinates the work of the program, conducts regular (both individually and in group) pastoral counselling, as well as creates, takes care of and maintains the traditions of the group. Prison chaplain as head of the group and at the same time as the leader brings into community (in the most direct way) Christian values and norms, both by teaching, with personal example, and also by the way she treats the members of the group.

I believe that within the prison subculture by offering the convicted persons not one but different types of leaders, from who the group members can select the leader, whose example they follow or do not follow, according to their personal interests and preferences, in prison hierarchical relationship model, which is characteristic for both prison subculture and prison management; it brings the democratic form of relationship, where the prevailing aspect is "You and I".

Martins Bubers comments on this type of relationship: "You and I" are holy primary words that form direct relationships between persons here and now. These are not disappearing and passing relationships, but they are expectant and guarding [20]. It is the kind of relationship, where people do not have opinion about each other, and that is why they are open to change. 


\section{Common table}

The important feature of the small group of prison subculture is a common table, which in its own way is a home substitute for a woman. The former convict poet Maira Asare, who has lived and studied in the "Miriam" program for two years of the total penal time, after her release published the book "Women Zone", where she wrote: "Often encountered relationships that are called "eating together". And it does not mean just sitting at the table during meals. It is almost a semi-legal term, and it includes both practical advantages, social life convenience, mutual trust, and silent longing of every convicted woman for family meals. In the simplified form, the common eating means coordinated shopping in a store and putting the bought items into the "common pot", and consequently the common eating" [21].

Sticking together in small groups guarantees also a kind of political protection. The stronger the group leader, with her prison authority, the safer feel other members of the group. Such grouping together may be justified by the fact that, firstly, thus women protect themselves from loneliness, and, secondly, they do not want to identify with all community of convicted women.

The principle of common eating is also embedded in the program "Miriam" in the way that for 16 women living in this program there is one well equipped kitchen, where they can cook and also spend time together during common meals. Although in such conditions this does not exclude the possibility of forming small groups also according to the living room principle. However, this kind of activity in the kitchen brings closer all 16 members of the program, and common meals occur quite frequently. The common meals are particularly important during holidays and festive occasions, for example, Christmas, Easter and birthdays, when the program participants gather in the kitchen to celebrate them together. The important common feast is the end of the school year, which takes place after the festive church service, receipt of the certificates, and presentation of the concert, for which members of the program duly and thoroughly prepare. Each festive table community strengthens the relationships within the group.

Within the "Miriam" community, which is created on Christian foundation, the common meal has also a spiritual perspective. It reaches a spiritual climax during the Lord's Supper service that takes place once a month in the "Miriam" chapel. This is the church service, which is celebrated according to the Lutheran tradition, however it is open to all members of the group. The service is ministered by chaplain, who is also the program manager, and is acquainted with spiritual needs of every member of the program. The Holy Communion, within the program, is available to each member of the program in accordance with her faith. Stanley Hauerwas, describing how the church service is celebrated in Tanzanian Maasai ethnic group, on the importance of unity during the Holy Supper, writes that it is a special communion, which does not unite morally complete, but rather those who have learned not to be afraid of each other and therefore are able to love. This meal in its own way is a symbol of peace, joy and benevolence, and it brings peace to the mutual relationships. Especially, if every day had been filled with hatred, lack of forgiveness and exclusion [22]. Hauerwas's observation of Maasai Christian community is also largely attributable to the "Miriam" community, which involves women, who have been declared by court's decision as "morally defective". In prison environment the convicted persons encounter all categories named by Hauerwas - hatred, lack of forgiveness, exclusion from both the community and from the group of other convicts, as well as from one's own part in relation to other people and society.

Hauerwas has named this type of community, represented by the "Miriam" community, a "servant community". It is important to distinguish between Hauerwas's understanding of the meaning of the word "servant", and the meaning of this word that has formed in social 
history. Hauerwas's definition of the word "servant": a member of society, who believes that he/she belongs to a certain community, who has a general understanding of values and norms, and who engages into social processes himself/ herself as a value, a giver, and a creator of community [23]. The convicted person, who is punished by deprivation of liberty and who lives separately from social processes, is being formed as consumer. The main goal of the program "Miriam" is to help the convicted person to see herself as a part of society, where she will return after serving her sentence, and to help this person to continue to see herself as creator of community.

\section{Space and time}

The extent, to which the convicted person will be an adept of the prison subculture, is also determined by the prison inmates' specific view on time and space, which reflects in the prison subculture, i.e., norms, values and cultural artefacts, and by which of these norms, values, cultural artefacts in female prison are in force in the small groups. The time and space perception exists in thoughts and sensations of the prison inmates, which arises because not only physical space is limited by the barbed wire fence and electrical wires, but because the living space of the convicted persons is also limited. Maira Asare, while being in pre-trial solitary confinement, describes this sense of time and space as follows: "The people of a very different culture and temperament are brought close together for a very long time. You could get the similar feeling in a closed train compartment, if it would be a months or years long journey, moreover, try adding the feeling, which arises from realization that the train does not go from one place to the other, but rather goes round and round in endless circles" [24].

Lennie Spitale on perception of space and time in prison: "It is not walls or fence, which separates them from freedom. It is not the towers with armed guards or the building floors with locked cells. It is not steel doors, or an electronic security system, or concrete floor, or fences, or countless rows of barbed wire. It is not dog teeth or keys in the hands of wardens. All those are just symbols. Much greater enemy of freedom is "time"" [25].

Although women, after having received the court's verdict, are sent to the partially closed prison, where moving is more free, but perception and sense of space and time overall stays the same. The sense of the convicted person of the living space, in contrast to freedom, is being affected by the fact that the prison does not have strict boundaries between private and public life [26]. Thus, a woman is constantly exposed not only to the official rules of prison life, determined by the regime activates, but also to informal rules, which although not to the extent as in male prisons, still organize lives of convicted women. There is no private space, which creates an acute problem - lack of privacy, time for a person to concentrate, reflect and assess, for instance, the committed crime and his/her future prospects in life. Lennie Spitale calls it a living in "aquarium society, from which it is impossible to escape and there is nowhere to hide. Not only other inmates know everything about you, but also the "big brother" is constantly watching over you [27]. This kind of existence is accompanied by fear and insecurity.

Time in prison seems to stop. It is no longer a linear flow, but it starts to spin in a circle. It becomes cyclic [28].

A person feels trapped not only in prison, but trapped between their past and future.

In prison, time is divided in two parts: before trial and after trial. Before trial a linear sense of time is distorted in the sense that a person, awaiting trial and verdict, does not know what will be the future events, which usually takes place in several stages. An arrested person during this period feels the time in cycles, from stage to stage, which ends only with court's verdict, because he or she at this stage is uncertain of dimension of the future, which Ernst Kasirers called a third dimension of time, and which is an indispensable element of time 
consciousness [29]. Kasirers believes that, in the structure of person's life, the relationship between the present and the future is even more important than relationship between the present and the past. He writes: "We live in a much more doubt and fear, excitement and expectations for the future, rather than in memories or in present adventures" [30]. "This period of time metaphorically can be compared to the chaos and void, as if it does not exist," writes Maira Asare [31]. The convicted women are being prepared for participation in this program already during the pre-trial period.

Following the court decision the convicted person gets a new starting point and a new calendar [32]. However, even this new countdown is a part of the cycle - from the date of arrest to the release date. Not only physical space, but also the sentence time itself becomes a prison. The convicted person begins to count years, days and sometimes even hours. Chronological time becomes the main reference object, and the release date becomes an idol. Lennie Spitale, who himself has experienced transformation of the point of view as a prisoner, admits that understanding of time, brought by Christianity, is able to transform the sense of time of the convicted person. He writes: "The Christian message can greatly transcend time and space" [33].

The Christian message in history of humanity has brought a linear understanding of time. Doctor of Theology G. Kalme writes: "The Christian faith is more of a time religion rather than space religion. It emphasizes such words as before, now and then" [34].

The Christian faith, while the convicted person is being in prison for a long time in an enclosed place with constant restrictions, can restore not only the linear sense of time, but also give a sense of security, which has been lacking. G. Kalme writes that from the Christian point of view the future "is safe for the mere fact that it is in God's hands, and that He must have set certain goals for the future" [35]. L. Spitale says, that the task of Christians, when going to prison to serve, is not to prepare the convicts for a great job outside, but to let them realize that not one single day has been wasted. It is not the task of servants to say that God will give peace to survive until the release date, but that in God can be found a lasting peace, available for every person right now" [36].

A convicted person can join the Christian program "Miriam" after the court decision, when one time cycle before the court's decision has ended and the next time cycle begins, which will end with the liberation day.

The theological understanding and sense of dimension of time and space is introduced into the program "Miriam" by Bible studies, discussions, conversations about the Christian message, which gives understanding of the spiritual dimension of the future. Religions (in case of the "Miriam" program in context of the Christian message) the future is no longer just an empirical fact, it includes the ethical and the religious task; as indicated by E. Kasirers: "[...] it is no longer mere expectations, but it becomes an imperative of a human life that goes beyond human's empirical needs and goes beyond the borders of empirical life" [37]. The future is no longer just a pathway along the chronological time spiral, by summing the daily events, which will someday end on an individual level, but the future obtains the perspective of eternity.

"Miriam" group also has practical manifestations of chronological time organization, associated with the Christian practice and Christian traditions. During the day the rhythm of the time is structured by the common morning and evening prayer, as well as services before the classes, which bring spiritual perspective. Sunday church services are important in structuring of the week and month time, but the flow of the whole year with the evangelical perspective, is structured by the major Christian holidays, which includes the celebration of Christian holidays, such as Christmas time and Christmas day celebration, Easter time and the celebration of Easter, Whitsunday and Whitsunday celebration. These holidays help to 
reduce the cyclic sense of time in prison, bringing the linear dimension of time, with the fact that the in the centre of celebration of these holidays is a church service. It includes evangelical message and the church service that are related to ritual activities, about which John Assmann says "these are the symbolic actions that exceed the primary purpose of the action" [38]. For example, the message of the festive church service on Christmas not only reminds the people of Christ's birth and significance of this event in the past, but also how it relates to each person receiving the message in the present and in the future, thus giving the future the above mentioned perspective of eternity.

The space problem in the "Miriam" group is addressed also by physical means. Firstly, by the fact that the program participants live conditionally separate from the other convicts, thus they are separated from the prison subculture impact as far as possible. Secondly, the program, unlike other departments, has another freely available room - a chapel, where program participants, during their free time, get the opportunity to "isolate" themselves from community public environment and to give into personal reflection in seclusion, in an appropriate environment. The fact that women live in one well-maintained room with 4 and not 7-12 persons and more, as it is in other Latvian places of confinement, creates favourable conditions to endure place of confinement and time limitations.

\section{Norms}

The prison subculture is characterized by the special informal norms and values that organize the prison community. According to majority of researchers, the prison subculture norms have emerged spontaneously, are applied on a voluntary basis among prisoners, and are aimed at helping convicted persons to survive in the harsh prison conditions on a daily basis [39]. In context of such understanding, and seeing the prison subculture from the ontognozeological aspect, this set of rules can be defined as a sort of prisoners' morality, for it regulates the actions of the convicted persons in a certain society and their behaviour towards other convicts [40]. Certainly, in prison conditions, applying it to the communion of convicted persons, this definition requires adjustment. However, just like outside the prison, also within the prison "morality is rooted in human nature" [..] and "it greatly depends on different cultural circumstances" [41].

One of the most expressive prison norms is violence by means of which the relationships problems are resolved. Although violence is more common in male prisons, still it also exists in female prisons. V. Zahars and M. Stivrenieks admit: "The analysis of the components of crime of the criminal offenses committed by women shows that the criminal offenses committed by women are becoming more aggressive, more brutal and better planned, which are often directly or indirectly related to alcohol, psychotropic or narcotic substance abuse or domestic violence" [42]. If a woman has tried to solve her problems in freedom by means of violence, then she will follow this interpersonal relationship model in problem situations also in prison conditions [43]. In male prisons the physical violence is more common, and in female prisons emotional and verbal abuse is more common.

The second most common subculture provision norm is the so-called prison slang or argot. In female prison argot is basically associated with the convicted persons' everyday life and it represents objects, actions and events. Like in male prisons, argot is also associated with criminal activities outside the prison [44]. According to Anrijs Kavalieris, the author of the criminal environment slang dictionary "The Way They Speak in Zone" on the time in Latvian prisons after retrieval independence says: “... after the Soviet years inertia, the Russian language was the main colloquial speech of the criminal and prison environment and with it - the slang of the Russian thieves ..." [45]. According to my experience and 
observations, it is still in use. Maira Asare in her book "Women Zone" has mentioned the following slang words used in Latvian female prison, for example, having it out with, sucker, showing off, criminal record, cakehole, fling, sing, for life, bud, pass-out, fiver, kite, henchman, builder's tea, gag, bullshit, commo, to bent upon, zilch, juvie, filer, parlour jump, etc. The specific subculture language, which is filled with slang words, among the convicts is called "talk slang" or "speak in criminals' argot" [46].

The philosopher Ilmars Shlapins explains the meaning of practical use of the slang words, pointing out the following models of use: the emphasis of one's identity, "clip someone's wings", duelling in verbal form, shock value, self-affectation, joke or irony reinforcement, disengagement, when talking about sexual function, romanticizing criminal offenses, by giving statements "poeticized look" in the criminal cultural context, expression of emotional affects [47]. It follows that the use of subculture language in prison serves as a method of survival within the whole community and within the small subculture group and not only within the small subculture group. According Hans-Georg Gadamer, the use of a language classically is understood as practice of mutual understanding, not as an activity but as a purposeful action, as a sort of living process, where some life communion lives. It is a form of communion, which creates language and is created by language [48]. J. Lotmans and B. Uspenskis explore the nature of language more profoundly. Both semiotics affirm that language, when it actually functions, is involved in a broader cultural system, creating a complex entirety. Language is the source in the centre of the culture that structures culture [49].

Language, culture and individual relationships in prison are like a complex entirety. Language structures the prison subculture and its subculture groups, while the prison subculture structures its adept. The convicted woman often does not realize that by using prison subculture language during many years, it gradually like a spider interweaves her into its culture web, because it has the power to control the thinking of the convicted person. L. Vigotskis confirms that thinking depends on speech and also the social and cultural experience. He also states that the relationship between thinking and speech is changing during development process, both quantitatively and qualitatively [50].

It follows, that structuring of other cultural facilities in prison, which would allow the opportunity of transformation of the point of view of convicted persons, should be started with the centre of community - with cleaning of the everyday language from the slang, with the help of a different language or its nominal value - learning of the new words, taking into consideration that words in female prison subculture conditions arealso the instrument of violence. Both these sub-cultural norms, violence and language in prison conditions, are conjugated together.

They have to learn the different spoken language in a sense that instead of connecting them to prison subculture, it would release them from it; not only helping them to survive in prison conditions, but also helping them to live after serving their sentence, which (life), according to Lennie Spitale's epithets, would be "soft" rather than "tough". However, the precondition is the person's wish to stop identifying himself/herself with the prison subculture, its norms and values.

Within the program "Miriam", as in small prison subculture group, the preached word has been placed in the centre of re-socialisation. It is learned in the form of sacred text, by reading, listening and learning different interpretations of the sacred text. The read and heard material is repeated and discussed. In this way, by repeating the text, the language gets transferred into speaker's vocabulary - from communication level to memory and thinking levels [51]. Becoming a part of thinking, it affects the person, and creates a different spoken language. Thus, by learning the "sacred word" and its related interpretation language, there is hope that the convicted person may experience the inner enlightenment, order and peace, 
sought by those convicted women who, on a voluntary basis chose to spend their sentence time in the program, as well as to experience transformation of the point of view.

In the program "Miriam", the Christian norms and the spoken language, which has been "cleaned" from the slang terminology, are acquired during Bible study courses, by studying Bible, according to so-called Emava model [52], where everyone is free to comment on the text, and by daily discussions with teachers and pastoral counselling with the program manager; as well as during lectures of art history and the history of sacred music, and discussing viewed films in the "Film Spiritual Dimensions" course, and also by writing essays, taking examinations at the end of the school year, learning to deal with conflict situations, pastoral counselling, creating everyday life of the spiritual community and participating in church services. The particular importance regarding formation of the spoken language has the attending of different art studios, for example, theatre studios and literature studios.

Throughout the whole learning process program participants learn to express the spiritual cognitions in simple, slang free colloquial language, by acquiring new specific terms during lecture courses. From my experience I can say that in order to acquire such slang free colloquial language, especially for those convicted persons, whose social degradation level is higher, it takes 1-2 years, so that use of such slang free language would become an internal desire and need. Even those women whose spoken language, and thus thinking, is not as saturated with argot, often have to learn to express their opinion on things and events in a spiritual manner. Thus, the program participants are involved in the process, which eventually can be compared to the mastering of a foreign language, where it is not just learning of words, but also feeling of the language, which creates a favourable environment for the transformation of thinking.

Language learning process, which can also be conditionally attributed to the participants of the program, is described by the philosopher Ernsts Kasirers. He believes that, for example, the most important thing in mastering a foreign language is to learn to develop concepts, in order to understand and communicate with the objective world. Thus, during this learning process the student positions himself/herself on a firm foundation and his/her indefinite, uncertain, inconsistent and obscure sensations begin to acquire a new form. It is as if they crystallize around the word, which is the focus of the thinking process. And everything in this sense that has been gained gives them a new perspective, extends and enriches the particular experience [53].

When mastering a different communication language in prison, within the program "Miriam", which is formed on the basis of the preached word, and is associated with religious, in this case, the word "religious" should be understood according to its Latin meaning religio, which is - scrupulosity, piety [54], and the ability to express oneself. The program participants are given a new perspective of communication and the opportunity of a new communion. E. Kasirers says: "The different organization and systematization of cohabitation manifests itself in language, myth, religion and art" [55]. In one's turn the new different communication languages, acquisition of art and religion, like in case of the program "Miriam", is a powerful impulse to create a different organization and systematization of cohabitation in prison.

\section{Values}

According to I. Lisak and Y. Cherkasova, although the definition of the prison subculture values does not differ greatly from definition of values in freedom, nevertheless their meaning and understanding have a great difference. Therefore the places of confinement have a specific value system [56]. 
H. Shvarts believes that the understanding of values is governed by three universal prerequisites: the individual's biological needs, the need for co-ordination of social interaction, survival need and wellbeing need [57]. In prison conditions the satisfaction of the abovementioned needs is limited, the coordination of the social interaction is also different, the wellbeing opportunities, and understanding "like in freedom" are also different, which is an essential precondition for understanding that unlike outside the prison, within the prison values have a different meaning and a different understanding.

J. Miller helps to understand this difference by providing his view on virtue in the context of ethics. According to J. Miller, a person's understanding of values is associated with their comprehension of " $I$ " and their basic estimates, which are enrooted in it, and consequently the way the wishes are selected that they choose to satisfy. Miller believes that selection of human desires is determined by his ideāls [58]. When it comes to the convicted person, their ideals and selection of desires have led them to violation of law and punishment by deprivation of liberty. The former repeat offender L. Spitale describes his awareness of "I", position in which he made his choices: "I am proud that I have been an outlaw and that I had an outlaw mentality. I have seen life through the lens of resistance. It was the part of who I am" [59].

However, not every convicted person, after having been sent to prison, has the same understanding of values and the same value priority. When he/she is forcibly sent to community, with limited freedom, particularly regime conditions, and where the aim of re-socialisation work is to minimize the criminality of the convicted person or to help him/her to change his/her criminal identity. The law-breakers create their own social community, where they can preserve their identity. Consequently, in the same social conditions the different convicted persons are able to agree on common values. S.H. Schwartz writes: "If a group of people give a certain value the same meaning, then it can be called like-mindedness, and it is the basis of the group's fundamental values [60]. The fundamental values of the prison subculture are also created according to this principle.

Such unanimous understanding of freedom in subculture of convicted persons has been called by I.V. Lisak and J.J. Cherkasova - the most important fundamental values of the prison subculture [61]. Convicted persons understand freedom as ability to be themselves, to remain the same under the pressure of unfavourable circumstances [62].

According to I.V. Lisak and J.J. Cherkasova the second most important fundamental value is dignity and honour [63]. Both in male and female prison dignity and honour are values, the meaning of which is determined by informal norms of the prison subculture. If the convicted person takes into consideration these norms and observes these norms, he or she has a good reputation and dignity.

According to I.V. Lisak and J.J. Cherkasova the next fundamental value is justice [64]. In the context of prison subculture the meaning of justice is understood in contrast to what is meant by injustice. The majority of convicted persons believe that the judicial system and their sentence are unjust. The convicted persons consider that the public attitude towards them, the prison regime and associated prison staff is also unjust. Therefore, everything that justifies the convicted person and allows him/her not to feel guilty is associated with justice.

The particular attention in prison is paid to material values [65]. Since in places of confinement the convicted persons are not allowed to hold currency, the material values, such as cigarettes, perfumery (in female prison), the permitted jewellery, the most demanded food products, if necessary, are used instead of currency. The convicted persons buy, sell and exchange different items, thus the prison subculture maintains a certain organization of economic life. Usually the wealthiest convicted persons assume in prison community the socially higher assessment. 
The fundamental values in the prison subculture are freedom, honour, respect, justice, and material values.

The values, which are dominant in prison subculture, are also significant in the Christian subculture. However, in Christian subculture they have a different meaning and understanding.

The acceptance of two fundamental values - beneficence and renunciation of status or humility (which came from Judaism) - of the Christian ethics helps to find the Christian understanding of values, prevailing in the prison subculture [66]. R. Kokin writes that "Love overcomes the horizontal boundaries between close people and strangers, and humility, breaks vertical boundaries - between people of different status and different levels of social layers" [...] "Beneficence is not the love for your relatives, friends and boyfriends/girlfriends, but it is the love for your enemies" [..]. And "to love your enemy always means the radical renunciation of the use of power" [67].

In the prison context both these fundamental values contradict the nature of the prison subculture, but they are the key for the turning point toward the point of view transformation. Therefore, I believe that in order beneficence and renunciation of status or humility to be accepted as values, first of all it is necessary for the convicted person to make a voluntary choice, and then it is necessary to create an environment figuratively "outside" the prison subculture, where to build a new community model, where the convicted person or persons would be able to experience these values "in relationships", because, according to R. Kokin: "The inner freedom, harmony and beauty are not worth a penny, if they are not experienced in the "outside", toward other people, if they do not manifest themselves in the active action that agreeably differs from everything we are accustomed to experience in society" [68]. Accepting fundamental Christian values means accepting their source. Martin Buber interprets R. Kokin's statement as follows: “A person can relate to God only when he/she becomes involved, where according to his/her own abilities, to the extent of each day, he/she "re-implements" God in the world [69].

Since the Christian program "Miriam" according to its content is the Christian subculture group representing Christian subculture values, these values are acquired during lecture courses on the Old and New Testament. During arts courses, such as theatre, music, fine arts, literature, students not only do acquire artistic skills under the guidance of the course teachers, but also discuss various personal issues. During these conversations the program participants are encouraged to think about fundamental Christian values.

Art itself brings a lot of values. A. Prieditis on importance of art: "Art is the most conservative element of culture, because traditionally it has been based on constant universal human moral norms and values" [70]. In practical theology art comes as a new perspective, which S. Ilmane and A. Shmit regard as a revelation of truth along with religion scriptures.

The program participants are encouraged to think about the Christian norms and values also in terms of community life, practically addressing problem situations under the pastoral guidance of the program manager. S.H. Schwartzwrites: "When we think about our values, we think about what is important regarding our security, independence, wisdom, success and prosperity of our life" [71]. The program participants are encouraged to think about what is important in their lives through the prism of fundamental Christian values.

\section{Artefacts}

The prison subculture is characterized by particular artefacts. The artefacts in culturology are artificially created objects, subjects, ideas, images, forms of behaviour, assessments, (..) terminology to describe artificially created worlds, namely, any element of culture [72]. 
Metaphorically cultural artefacts can be compared to the tip of an iceberg that peaks out of the cultural layer and are the message about what kind of persons make up this cultural layer or cultural space.

I.V. Lisak and J.J. Cherkasova have named the main prison subculture artefacts: prison lyrics - the so-called argotic songs, tattoos, jokes, self-made postcards, letters to home, etc. [73]. In female prison these artefacts are: handcraft, arrangement of their living place, clothing style, hair style or coloration, allowed cheap jewellery, behaviour type, etc.

According to culturology all types of prison amateur works, which by their form are more associated with the street culture, can be considered artefacts. The purpose of their use from of the emotional aspect is either to entertain or to call the sentimental memories of life in freedom. During re-socialisation events, organized in prison, where the convicted persons are invited to show their skills in different types of amateur works, according to my observations, prison subculture artefacts are also reproduced. These are the dances, songs, poetry, short dramatic performances on prison life, memories of home or with elements borrowed from Russian TV entertainment shows.

The convicted person wants to be effective in prison subculture. This person wants to be noticed and appreciated. Skilful creative implementation and use of artefacts in prison helps to fulfil these desires. For instance, if someone has the ability to write letters, or to draw cards, or to fashion another handicraft that can be sent home, this convicted person is respected by other inmates. Such creative activity, using public space ruling terminology, makes the convicted person successful in a given environment. Erik Fromm writes: "When a person is aware of the environment in which he lives, with all its peculiarities and dangers, in order to save his individuality, his $I$, he using his creative capacity does every, in order to get noticed. He tries to be effective. It means to recreate something, implement, carry out, execute, to have the capacity to act, etc. He is active in a given culture, not only so that others would impact him, but also for him to impact others. Such behaviour indicates that a human is not weak and helpless thing. And that means existing in a particular culture" [74].

This way the convicted person raises his/her self-esteem and is noticed and evaluated in prison subculture. However, even though the prison subculture stimulates creative processes, it is focused on the convicted person's criminal identity preservation rather than transformation. This can be effectively demonstrated, metaphorically speaking, by peeling off layers of prison subculture like onion peel. K. Gircs writes: "If you tear off colourful mottled shapes of culture, you will be able to see structural and functional regularities of social organization. If you tear off these regularities, you will see psychological factors "basic needs" or whatever they are called, which support the abovementioned regularities; the remaining are biological-anatomical physiological and neurological foundations of a mighty house of human life" [75].

The participants of the Christian program "Miriam" are offered to get acquainted with Christianity specific artefacts. Often they are also used in the prison subculture, for example, in tattoos the cross sign is often used, lilies, as well as Christian terminology, without understanding their meaning and the essence in the context of Christianity. Within the program "Miriam" the students can get acquainted with Christian artefacts during lectures and art courses, such as images and ideas of Christianity, as well as living in the community behavioural forms, evaluations, etc. The knowledge and use of these artefacts point to the other identity, other relationship models, other attitude towards the surrounding society and other understanding of $I$, which is no longer associated with the criminal environment. These are the signs toward exploring and acquisition of other cultural space.

During arts courses the convicted persons study Western art-specific artefacts. For example, fine arts studio program participants explore the French impressionist artists of 
the time, get acquainted with their works and create copies of these works, and only then they make their own original works. At the end of the training year an exhibition takes place, which can be attended by all prison inmates. The visitors of the exhibition acquaint themselves with local artefacts - copies of the French impressionists, and thus seeing artefacts that are typical for French impressionism, such as the Van Gogh's sunflowers, wheat field with cypresses, etc.

In prison subculture the familiarization and learning about Western art artefacts encourage the adoption of different aesthetic ideals and different aesthetic tastes, opposite to that the ideals and tastes that dominate in prison subculture. A. Prieditis writes: "One of the most specific features of the art is that art is able to effectively transform aesthetic ideals and aesthetic taste, which exist in culture" [76]. Aesthetic ideals and tastes of female prison are closely linked with the prevailing values and norms. Consequently, to transform the aesthetic ideals also means to affect the existing norms and values. I believe that the program participants, who attend one or more arts courses, and who attend the studies voluntarily, as provided by the program regulations, rather than by compulsion, are exposed to art more deeply and art has an in-depth impact on the convicted persons. Art, as it is seen today, affects the human's personality, socialization and gives knowledge of culture, involving individuals into society and its topical system of morality, aesthetic, philosophical ideas and values [77]. R. Ilman and A. Smith write: "Art is capable to touch us not only as rational beings, but as complex entities with their own experience, feelings and attitudes; with hopes for the future" [78]. Art is also a reflection of the artefacts of the certain period of time.

Each art course of the program "Miriam" is established on the basis of creative activities that are topical in female prison subculture. Opposite to desire to express oneself by drawing, the program offers a fine art studio, opposite to desire to sing and play, for example a guitar, which in prison is a popular musical instrument, the program offers the opportunity to attend a music studio, under the guidance of professional musicians - to sing Gospel, learn to play a guitar, kokle, jambi rhythms. Opposite to desire to stage performances in prison with scenes of prison life, the program offers theatre courses, where participants can stage classical plays. Opposite to desire to read detective novels and cheap literature, the program offers socially topical literature in the literary studio. Opposite the desire to knit socks and scarves in prison, the program offers courses, where these skills are taught as the applied arts. In every studio the communion and fellowship are also important, forming a favourable environment for adaptation of the artefacts of the other culture, under the guidance of the course teacher. A different cultural environment, which is being built in the "Miriam" program, in addition to the existing prison subculture environment, offers to engage in any other type of artistic activities, it offers to adapt other images, other ideas, other forms of behaviour, other assessments. The program "Miriam" shapes a different cultural environment with other artefacts.

The program's name and logo are also considered to be the atypical Christian subculture artefacts, which in female prison have become the fiducial marks of the program "Miriam". The program's logo picture contains a photo fragment of the upward leading staircase toward "Miriam" chapel and the portrait of Mary the mother of Jesus; a fragment from an unknown author's work. Program's name "Miriam" is an etymon of the person's name Maria, symbolically representing the desired path of each member of the program, restoring relations with the Creator and returning them to the socially acceptable relationship with fellow human beings.

Christianity and Western art-specific artefacts that are acquired within the program "Miriam" refer to the different identity, different ethical and aesthetic ideals, to the different understanding of "I" and are no longer associated with the prisoner subculture, and encourage the creation of the different cultural environment. 


\section{Summary}

The precondition of success of the program "Miriam", in order to exist in the convict created social structure, and to bring into it different cultural values and norms, thus facilitating the transformation of point of view of the convicted persons, is that this program has been established as one of the small subculture groups, with small group characteristic features. It has its own leaders, a common table, norms, values, artefacts and a sense of time and space. Although the features are formally the same, still they differ in content.

An important factor for the existence of a small group is group leaders, who in the prison subculture have a certain power over other convicted persons. They ensure the existence of prison subculture morality and ethics. The "Miriam" program leaders are not power oriented, but rather service oriented. They propose different values, norms, aesthetic and ethical ideals, that do not bind and enslave, but which release from prison subculture obligations. These leaders are teachers - intellectuals, culture and art workers with good public reputation, who are decent representatives of their profession. An important leader is the program manager, the prison chaplain, who in the most direct way brings Christian values and norms into community by teaching, through pastoral counselling, organizing and coordinating the work of the group. The chaplain's assistant is the "elder sister" of the group, who is both a formal and informal leader, because she is elected by both the program participants and the prison administration.

The second important feature of the prison subculture is a common table in a small group, which is characterized by common meals, common product procurement, social and political protection. In its turn, common table within the program "Miriam" has both sociologically practical significance forming community, as well as spiritual significance in the context of Christianity. During celebration of religious holidays within the program, the common meal acquires a spiritual perspective and reaches its peak at Lord's Supper service, which is the symbol of peace, joy and benevolence, the meaning of which is to unite the different and the marginal.

The prison inmates' perception of time and space is quite specific, and it exists in thoughts and feelings of convicted persons. The time in places of confinement becomes cyclic. The Christian message that is preached and taught within the "Miriam" brings and restores a linear sense of time, and gives the missing feeling of security, because the time spent in prison is no longer perceived as a cyclic chronologic time, but it acquires the perspective of future, which goes beyond the empirical boundaries. The sense of time and space are spiritually connected. The space problem in the "Miriam" group is addressed also by physical means. Firstly, by the fact that the program participants live conditionally separate from the other convicted persons.

The set of rules of prison subculture, which govern the relationships of convicted persons within the community, can be considered as kind of prisoners' morality. The main rules are violence the prisoners' slang or argot, which structure the colloquial language of subculture. The language in prison is the centre of subculture community, and it serves as communication, relationship and violence tool. The "Miriam" program brings to prison the Christian norms and liberates the spoken language from the slang. It is mastered during Bible studies, discussions, discussions with teachers and pastoral counselling with chaplain and art courses, and offers a new violence free way of intercommunication.

Although the definition of the values of prison subculture formally does not differ greatly from definition of values in freedom, nevertheless their meaning and understanding have a great difference. The main values, which are important both for the prisoner community and within the program "Miriam", are freedom, honour and respect, justice and material values. In the Christian context, these values have a different meaning and significance. 
The acceptance of Christian ethics central values - beneficence and renunciation - helps to find the Christian understanding of these values in the prison subculture. In the prison context both these fundamental values contrary to what is valuable to prison subculture, but they are the key for the turning point toward acceptance of different values, which is an important precondition of transformation of the point of view of the convicted person. The "Miriam" program is designed so that these fundamental values would be taught, learned and experienced in relationships in the group community.

A characteristic feature of the prison subculture is the prison the prison artefacts, which are the tip of the iceberg that peaks out of the cultural layer and are the message about, what kind of persons make up this cultural layer or cultural space. These artefacts are related to preservation of prison subculture norms and values, and they strengthen the sentenced persons' criminal identity. The Christian program "Miriam" offers its participants to get to know artefacts that are typical for Christianity that point to a different identity. During arts courses the convicted persons study Western art-specific artefacts, so that program participants would accept the aesthetical and ethical ideals that are associated with them, thus raising interest about cultural environment to which these artefacts are related.

Within the program "Miriam", with the help of implemented means of re-socialisation, features that are recognized in the prison subculture, acquire other content.

\section{References}

[1] Eduards Dž. Vīts, Postmodernie laiki. tulk. Inguna Zarite (Rīga: Luteriskā mantojuma fonds, 1999). 156.lpp.

[2] Lennie Spitale, Prison Ministri. Understanding Prison Culture Inside and Out (Nashville, Tenneessee: B\&H Publishing Group, 2002), 34.

[3] И.В. Лысак, Ю.Ю. Черкасова, Тюремная субкультура в России (Таганрог:Издательство Таганрогского государственного радиотехническогоуниверситета, 2006), 37.

[4] Renee A. Meyers, et al. Understanding Groups From a Feminist Perspective. in Theories of small groups. Interdisciplinary perspectives. edit. Marshall Scott Poole, Andrea B. Holingshead (Thousand Oaks, Calif: SAGE Publications, 2005), 254. [skatīts 17.04.2015]. Pieejams tiešsaistē: http://eds.a.ebscohost.com/eds/ ebookviewer/ebook/bmxlYmtfXzQ3Nzk0MV9fQU41?sid=090746e6-7409-460c8651-d090a3393109@sessionmgr4001\&vid=6\&format $=$ EB\&rid=2

[5] И.В. Лысак, Ю.Ю. Черкасова, тюремная субкультура в России (Таганрог:Издательство Таганрогского государственного радиотехническогоуниверситета, 2006), 37.

[6] Joanne Belknap, The Invisible Women. Gender, Crime, and Justice (Wadsworth: Cengage Learning, 2007), 214.

[7] И.В. Лысак, Ю.Ю. Черкасова, тюремная субкультура в России (Таганрог:Издательство Таганрогского государственногора диотехническогоуниверситета, 2006), 37.

[8] Lennie Spitale, Prison Ministry. Understanding Prison Culture Inside and Out (Nashville, Tenneessee: B\&H Publishing Group, 2002), 60-62.

[9] Joanne Belknap, The invisible Women. Gender, Crime, and Justice (Wadsworth: Cengage Learning, 2007), 216.

[10] Maira Asare. Sieviešu zona (Rīga: Dienas grāmata, 2009), 102.

[11] Maira Asare. Sieviešu zona (Rīga: Dienas grāmata, 2009), 104. 
[12] Lennie Spitale, Prison Ministry. Understanding Prison Culture Inside and Out. (Nashville, Tenneessee: B\&H Publishing Group, 2002), 102, 92, 88.

[13] Robert K.Greenleaf, The Servant as Leader [skatīts 14.03.2015]. Pieejamstiešsaistē: https://www . leadershiparlington.org/pdf/TheServantasLeader.pdf

[14] Robert K. Greenleaf, The Servant as Leader [skatīts 14.03.2015]. Pieejamstiešsaistē: https://www . leadershiparlington.org/pdf/TheServantasLeader .pdf

[15] Martins Būbers, Es un Tu, tulk. Igors Šuvajevs, (Rīga: Zvaigzne ABC,2010), 54.

[16] Robert K. Greenleaf, The Servant as Leader [skatīts 14.03.2015]. Pieejamstiešsaistē: https://www. leadershiparlington.org/pdf/TheServantasLeader.pdf

[17] И.В. Лысак, Ю.Ю. Черкасова, Тюремная субкультура в России (Таганрог:Издательство Таганрогского государственного радиотехническогоуниверситета, 2006), 37.

[18] Lennie Spitale, Prison Ministry. Understanding Prison Culture Inside and Out. (Nashville, Tenneessee: B\&H Publishing Group, 2002), 102.,92.,88.

[19] Daniel Glaser, The effectiveness of a prison and parole system, (Indianapolis: BobbsMerrill, 1964), 145.

[20] Martins Bubers. Es un Tu, tulk.Igors Šuvajevs (Rīga: Zvaigzne ABC, 2010), 11-19.

[21] Maira Asare. Sieviešu zona (Rīga: Dienas grāmata, 2009), 68.

[22] Stanley Hauerwas, "The Servant Community: Christian Social Ethics" The Hauerwas Reader (Duke University Press, 2001), 386.

[23] Stanley Hauerwas, "The Servant Community: Christian Social Ethics" The Hauerwas Reader (Duke University), 370-391.

[24] Maira Asare. Sieviešu zona (Rīga: Dienas grāmata, 2009), 26.

[25] Lennie Spitale, Prison Ministry. Understanding Prison Culture Inside and Out (Nashville, Tenneessee: B\&H Publishing Group, 2002), 13.

[26] И.В. Лысак, Ю.Ю. Черкасова, Тюремная субкультура в России (Таганрог:Издательство Таганрогского государственного радиотехническогоуниверситета, 2006), 33.

[27] Lennie Spitale, Prison Ministry. Understanding Prison Culture Inside and Out (Nashville, Tenneessee: B\&H Publishing Group, 2002), 79.

[28] И.В. Лысак, Ю.Ю. Черкасова, Тюремная субкультура в России (Таганрог:Издательство Таганрогского государственного радиотехническогоуниверситета, 2006), 52.

[29] Ernsts Kasīrers, Apcerējums par cilvēku, tulk. Sandra Rutmane, Aija Siltāne (Rīga: Intelekts, 1997), 59.

[30] Ernsts Kasīrers, Apcerējums par cilvēku, tulk. Sandra Rutmane, Aija Siltāne (Rīga: Intelekts, 1997), 59.

[31] Maira Asare. Sieviešu zona (Rīga: Dienas grāmata, 2009), 26.

[32] И.В.Лысак, Ю.Ю. Черкасова, Тюремная субкультура в России (Таганрог:Издательство Таганрогского государственного радиотехническогоуниверситета, 2006), 52.

[33] Lennie Spitale, Prison Ministry. Understanding Prison Culture Inside and Out (Nashville, Tenneessee: B\&H Publishing Group, 2002), 19.

[34] Guntis Kalme. "Kristus - laika un Vēstures Kungs (kristīgās laika teoloğijas pamatprincipi)"// Kristietība pasaules kultūrā, Zinātniska konference 2000. gada 12-13. maijs R̄̄ga, red. Anita Kalniņa (Rīga: Vārds, 2000), 29.

[35] Guntis Kalme. "Kristus - laika un Vēstures Kungs (kristīgās laika teoloğijas pamatprincipi)"// Kristieț̄ba pasaules kultūrā, Zinātniska konference 2000. gada 12-13. maijs Rīga, red. Anita Kalniņa (Rīga: Vārds, 2000), 29. 
[36] Lennie Spitale, Prison Ministry. Understanding Prison Culture Inside and Out (Nashville, Tenneessee: B\&H Publishing Group, 2002), 21.

[37] Ernsts Kasīrers, Apcerējums par cilvēku, tulk. Sandra Rutmane, Aija Siltāne, (Rīga: Intelekts, 1997), 61.

[38] Jan Assmann, "Form as a Mnemonic Device: cuttural Texts and Cultural Memory," Performing the Gospel. Orality, Memory, and Mark, Richard A. Horsley, Jonathan A. Draper, John Miles Foley (Hg.) (Fortress: Minneapolis, 2006), 71.

[39] И.В. Лысак, Ю.Ю. Черкасова, Тюремная субкультура в России (Таганрог:Издательство Таганрогского государственного радиотехническогоуниверситета, 2006), 39.

[40] Svešvārduvārdnīca (Rīga: Jumava, 1999)

[41] Regnars Holte "Kur sakņojas morāle"// Ėtikasdimensijas, sast. Normunds Kamergrauzis (Rīga: Svētdienas Rīts, 1997), 9.

[42] V. Zahars, M. Stivrenieks, "Security implementation facets: convicted women imprisonment sentence execution," Journal of security and sustainability issues, nr. 3. (Dec. 2014): 46.

[43] И.В. Лысак, Ю.Ю. Черкасова, Тюремная субкультура в России (Таганрог:Издательство Таганрогского государственного радиот ехническогоуниверситета, 2006), 53.

[44] И.В. Лысак, Ю.Ю. Черкасова, Тюремная субкультура в России (Таганрог:Издательство Тагнрогского государственного радиот ехническогоуниверситета, 2006), 54.

[45] Anrijs Kavalieris, Tā runā zonā (Rīga: Valtersun Rapa, 2002), 7.

[46] Anrijs Kavalieris, Tā runā zonā (Rīga: Valtersun Rapa, 2002), 7.

[47] Ilmārs Šlāpins. Lamu vārdu funkcionalitāte latviešu un krievu valodās[skatīts 09.02.2015]. Pieejamstiešsaistē: http://www.satori.lv/raksts/izdruka/2003

[48] Hans Georgs Gadamers, Patiesība un metode. tulk.Igors Šuvajevs (Rīga: Jumava, 1999), 415.

[49] Jurijs Lotmans, Boriss Uspenskis "Par kultūras semiotisko mehānismu"//Kultūra, teksts, zīme, sast.un tulk. Igors Šuvajevs(Rīga:Elpa, 1993), 42.

[50] Ļevs Vigotskis, Domāšanaunruna. tulk. Marita Freija (Rīga: Eve, 2002), 118, 88.

[51] Jan Assmann, "Form as a Mnemonic Device: cuttural Texts and Cultural Memory," Performing the Gospel. Orality, Memory, and Mark, Richard A. Horsley, Jonathan A. Draper, John Miles Foley (Hg.) (Fortress: Minneapolis, 2006), 72.

[52] Urlika Erlandsone, "Emavas modelis"//Bībeles studiju metodes, tulk.Vita Bukaldere (Rīga: Latvijas Bībeles biedrība, 2002), 21-25.

[53] Ernsts Kasīrers, Apcerējums par cilvēku, tulk. Sandra Rutmane,Aija Siltāne (Rīga: Atklātais sabiedriskais fonds "Intelekts",1997), 130.

[54] Lija Čerfosa, Tamāra Fomina, Pāvils Zicāns, Latīņu valoda (Rīga: Zvaigzne, 1974).

[55] Ernsts Kasīrers, Apcerējums par cilvēku, tulk. Sandra Rutmane, Aija Siltāne (Rīga: Atklātais sabiedriskais fonds "Intelekts", 1997), 71.

[56] И.В. Лысак, Ю.Ю. Черкасова, Тюремная субкультура в России (Таганрог:Издательство Таганрогского государственного радиотехническогоуниверситета, 2006), 55.

[57] Ibid.

[58] Jorans Millers "Kur sakņojas morāle"// Ëtikasdimensijas, sast. Normunds Kamergrauzis (Rīga: Svētdienas Rīts, 1997), 73-75.

[59] Lennie Spitale, Prison Ministriy. Understanding Prison Culture Inside and Out (Nashville, Tenneessee: B\&H Publishing Group, 2002), 28. 
[60] Shalom H. Schwartz, Basic Human Values: Theory, Methods, and Applications [skatīts 10.02.2015]. Pieejamstiešsaistē: http://segr-did2.fmag.unict.it/Allegati/ convegno\%207-8-10-05/Schwartzpaper .pdf

[61] И.В.Лысак, Ю.Ю. Черкасова, Тюремная субкультура в России (Таганрог:Издательство Таганрогского государственного радиотехническогоуниверситета, 2006), 55.

[62] А.Н. Олеиник, Тюремная субкультура в России: от повседневной жизни до государственной власти (Москва:Иифра - М, 2001), 171.

[63] И.В. Лысак, Ю.Ю. Черкасова, тюремная субкультура в России (Таганрог:Издательство Таганрогского государственного радиотехническогоуниверситета, 2006), 56.

[64] Ibid.

[65] И.В. Лысак, Ю.Ю. Черкасова, тюремная субкультура в России (Таганрог:Издательство Таганрогского государственного радиотехнического университета, 2006) $57.1 \mathrm{pp}$

[66] Ralfs Kokins, "Kristīgās ètikaspamatvērtības - mīlestībaunpazemība"// Teoloǵija: teorijaunprakse, sast.J.Rubenis (Rīga: ZvaigzneABC, 2007), 138.

[67] Ralfs Kokins, "Kristīgās ètikaspamatvērtības - mīlestībaunpazemība"// Teoloǵija: teorijaunprakse, sast. J. Rubenis (Rīga: ZvaigzneABC, 2007), 139-142.

[68] Ralfs Kokins, "Kristīgās ètikaspamatvērtības - mīlestībaunpazemība"// Teoloǵija: teorijaunprakse, sast. J. Rubenis (Rīga: ZvaigzneABC, 2007), 134.

[69] Martins Būbers, EsunTu, tulk. Igors Šuvajevs (Rīga: ZvaigzneABC, 2010), 95.

[70] Arturs Priedītis, Ievadskultorolog̣ijā (Daugavpils: A.K.A. 2003), 65.

[71] Shalom H. Schwartz, Basic Human Values: Theory, Methods, and Applications [skatīts 10.02.2015]. Pieejams tiešsaistê: http://segr-did2.fmag.unict.it/Allegati/ convegno\%207-8-10-05/Schwartzpaper.pdf

[72] Arturs Priedītis, Ievads kultorolog̣ijā (Daugavpils: A.K.A. 2003), 202.

[73] В. Лысак, Ю.Ю. Черкасова, Тюремная субкультура в России (Таганрог: Издательство Таганрогскогогосударственного радиотехническогоуниверситета, 2006), 59.

[74] Ерик Фромм, Анатомийа человеческой деструктивности (Москва:Респу блика, 1994), 205.

[75] Klifords Gīrcs, Kultūruinterpretācija, tulk. Agita Lūse (Rīga: AGB, 1998), 42.

[76] Arturs Priedītis, Ievadskultorolog̣ijā (Daugavpils: A.K.A. 2003), 93.

[77] Arturs Priedītis, Ievadskultorolog̣ijā (Daugavpils: A.K.A. 2003), 96.

[78] Ruth Ilman, W. Alan Smith, Theology and the Arts (New York and London: Taylor\&Francis group, 2013), 31. 